\section{Senior-Junior Academic Exchange: Building Administrative
Capacity}

Sunil Tankha received his doctorate from MIT and is a lecturer in the Institute of Social Studies at Erasmus University Rotterdam. His teaching and research involves public policy and management, and economic infrastructure development, with several years of field experience in Latin America, South Asia, and Africa. E-mail: tankha@iss.nl

\title{
Building Administrative Capacities in Developing Countries: SWAT Teams or Beat Cops?
}

After reading Professor Ali Farazmand's essay "Building Administrative Capacity in the Age of Rapid Globalization: A Modest Prescription for the Twenty-First Century," one is reminded that the list of capacities we need to develop is long, the tasks are diverse, and the challenges are tremendous. By offering a "modest" prescription, Farazmand departs emphatically from recent attempts to rewrite administrative capacity by downgrading it and outsourcing it to the market or by making it imitate corporate structures and techniques. Such exercises of yesteryear are correctly being excoriated now, but it would be well to remember that this failed model was inspired and facilitated by the stagnation and many perversities of the state-centered model that it replaced. As we stand at the cusp of a new generation of public administration reforms, we are reminded by Professor Farazmand's exposition that we no longer have any widely accepted and integrative theories left to guide our practice of reform, and that a search must begin to look at past evidence with a critical eye toward developing practical and theoretical insights to advance the public administration agenda.

s Professor Farazmand's article speaks for glo-
bal public administration rather than the pub-
lic administration of any particular country or any particular subfield, such as disaster management (though it is written for all countries and has a distinct discussion of crisis and emergency management), this short response addresses in some detail the particular needs of developing countries, where the vast majority of human beings live. Professor Farazmand correctly recognizes that as a prerequisite to promoting development-oriented governance, it is necessary to break the detrimental external influence of advanced industrial countries and multinational corporations on policy choices in developing countries. The reform models that were recommended to developing countries, sometimes imposed and sometimes embraced, were theoretically plausible and practically appealing but nevertheless wrong because there could never have been sufficient resources available to back up the subtle yet sophisticated tasks that were created for the new public administration. In one set of cases, financial resources were lacking and the institutions created to perform the regulatory functions of government were perfunctory, matching their objectives in form but unable to match them in function. In another set of cases, the human resources were lacking.

Sufficiently capable administrators could not be found, especially because the general ill will toward and budget constraints on the public sector steered the brightest minds to the private sector, where they responded to a different set of incentives. In a third set of cases, the institutional requirements could not be met because social capital was elusive or because these institutions, burdened by their colonial history and structures, responded to a new set of equally predatory masters rather than to citizens. There was considerable overlap in these cases: most developing countries suffered from all three and other shortcomings, and in the absence of these resources and conditions, the cause-effect chains predicted by the orthodox theories underlying reform could not occur. 
More importantly, theoretical biopsies also show that even in the presence of these resources, the cause-effect chains would not necessarily occur. The work of heterodox informational, institutional, and political theorists indicates serious flaws in the assumptions of these theories. This literature highlights theoretical flaws in the neoclassical economics underpinning orthodox conceptualizations, recommendations, and strategies for reform. It contradicts the claim that market-driven systems result in inevitable and uniquely high-level equilibria by showing the existence of multiple equilibria and multiple channels that shift societies and reestablish them in different equilibria. Long-recognized development problems, such as those of coordination, posited by Rosenstein-Rodan (1951), illustrated by Hirschman (1988), and formalized by Stiglitz and others (see Hoff and Stiglitz 2001), were misdiagnosed and underestimated by the orthodoxy. Indeed, phenomena critical to economic development, such as clustering (of industry, knowledge, and so forth), go against the predictions of neoclassical reasoning, implying that markets are a many-layered phenomenon, and even if markets are the underlying basis for a system, they act in concert with a number of other institutional factors that operate separately from the underlying logic of markets. Instead of acknowledging and coping with these issues, it was shown by pithy mathematical models that the market could easily solve these and other coordination problems, but none of these were backed by solid empirical evidence.

Another literature, through grounded empirical and political analysis, accuses the orthodoxy of obfuscating and obstructing knowledge about development paths. At the heart of these analyses are demonstrations showing that state-led interventions that go against the grain of neoclassical market analysis can be virtuous in shifting developing-country economies to higher growth paths. Amsden (1989) and Rodrik (2007) analyze examples, including Korea and China, of development successes that were achieved specifically by heavy government manipulations in market-mediated exchanges, providing a wealth of knowledge about how hybrid forms of state-market institutional and strategic arrangements can serve developmental objectives. But the heterodox lessons from East Asia's development success were marginalized as well as misinterpreted by the orthodoxy, as in the case of the World Bank's East Asia Miracle (1993), in which it tried to argue that market interventions were ultimately useless because they resulted in the same strategies and allocations of resources that would have resulted had the "free market" been allowed to reign supreme (Amsden 1994; Kwon 1994; Perkins 1994). Ha-Joon Chang (2002), in another heterodox approach, correctly points out that, in fact, what the Washington Consensus preached were not the strategies that Western countries had followed when they themselves were modernizing their economies. As the neoclassically recommended development models were not the ones that were practiced, their policy advice cannot claim to come from experience-based knowledge or claim the legitimacy of successful experience. In the absence of this legitimacy, it is not surprising that many in developing countries view Western policy advice as predatory and a hypocritical continuation of past exploitative relationships, colonial and otherwise. It is against these hegemonic tendencies, backed by a narrow branch of economic theorizing, that the counterbalancing forces that Professor Farazmand refers to, when he asserts that "capitalism is not inherently evil or against the masses of people," must act.

The damage wrought by orthodox policy advice was not restricted to the macroeconomic policy arena. At the institutional level, advice that hollowed out the state was detrimental to developing the very capabilities that Professor Farazmand identifies as necessary to address the challenges of public administration. In developing countries, the negative effects of this policy advice were made apparent through the "orthodox paradox," whereby scholars found that a strong state is necessary to manage its own retreat and to establish freer markets, which need more rules (Haggard and Kaufman 1992). Moreover, restricting the scope of public administration, especially in its developmental mission, resulted in timidity in investing public resources - technical, managerial, and, especially, financial — to address pressing challenges. Professor Farazmand is correct in asserting that the capacity to manage basic challenges and provide public services has diminished considerably. If developing countries are now to reach the Millennium Development Goals established by the United Nations, it will require more aggressive and concerted public action mediated through democratic governance. Once we can intellectually reject simplistic theories, we can move more toward the critical challenge that Professor Farazmand alludes to, that of "managing public governance and administration in this emerging global environment of rapid changes and hyper-complexities."

In highlighting the challenges of this intellectual discourse, Professor Farazmand provides a useful overview of the various strands of public administration theory and practice. But while the scope of his article is its strength, it is also its weakness. From the point of view of developing countries, where the vast majority of people live, the article's approach to building a new administrative capacity does not resonate. The central question raised is whether traditional administrative capacities are good enough to meet the new challenges ahead. Professor Farazmand acknowledges the value of these traditional capacities, but claims that they "are not" and asserts that public administration systems must maintain a full "anticipatory" capacity and "stand ready" to meet unknown future challenges. But developing-country administrations are unprepared to face the challenges of today, let alone those of tomorrow. They are inefficient-perhaps not with respect to their current endowment of resources or their history, but certainly with respect to the demands and targets that we as a society have established for them.

While the problems facing public administration will undoubtedly become more complex, the need of the hour is more to distinguish routine problems that lead to crises in the everyday lives of poor people in developing (and often developed) countries—such as the 
inability to provide sanitation in India, to remedy gang violence in the favelas of Rio de Janeiro, to control malaria in East Africa, and to ensure women's rights-from unpredictable mega-events such as tsunamis and hurricanes. By all accounts, these daily crises take much more of a toll in terms of lives lost and economic costs incurred than terrorism or sudden natural calamities, and they do not resolve themselves automatically with economic growth; indeed, in the presence of significant inequalities in income and power, they may become even worse.

Given that it is unlikely that there will be a massive increase in the resources available-rich countries are not willing to substantially increase their aid outlays, a situation that is made worse by the widespread practice of tying aid-or allocated to meet these challenges, the onus for improvements will rest on the creation of knowledge about and diffusion of good public administration management and practices. Maintaining a full "anticipatory" capacity to "stand ready" to meet unknown future challenges cannot but absorb massive amounts of financial and human resources in maintaining the necessary administrative redundancy. One does not normally employ SWAT teams for policing the beat, and not all beat cops can be trained to SWAT team levels of effectiveness. Given that developing countries cannot afford to have both, the burning questions are where do we find the necessary resources, and how should we allocate them?

The objective before public management in developing countries, therefore, is to manage more, with fewer resources, but with more skill. This calls for a renewed focus on good government, as opposed to good governance, as the latter may be misconstrued to mean that alternative institutions such as nongovernmental organizations and community-based organizations can supplement governments, when, in reality, they can only complement them, and that, too, in limited and selective arenas.

Because the traditional administrative capacities that Professor Farazmand claims will be inadequate are not explicitly defined-he assumes we all know them-one must imagine that he is referring to the Weberian systems of bureaucratic administration in their various forms. One can appreciate the limitations of Weberian systems in dealing with unexpected crises that challenge standard operating procedures, but in developing countries, it is the manipulation and subversion of standard operating procedures that are more responsible for the inability to deliver public services.

In developing countries, the origins of this manipulation lie in the political sphere and its interaction with public administration, but Professor Farazmand addresses the relationship between politics and administration only in passing. Indeed, some of the events that he cites, such as the Hurricane Katrina fiasco in New Orleans, indicate that the problem of political manipulation of administrative structures is not only a developing-country phenomenon. One critical area of concern is campaign finance. The recent scandal in
Brazil involving the Lula administration, the ubiquitous Caixa Dois of Brazilian politics, and the constant manipulation of the "transfer system" of bureaucratic postings in the Indian administrative system all originate in this sphere and have a damning impact on administrative morale and effectiveness.

We still need to solve the twentieth-century problems of public administration before we can have any hope of building twentyfirst-century administrative systems. Solving these problems first will provide the necessary base for building the types administrative capacities that Professor Farazmand recommends. In the quest to develop the required knowledge and skills, there is no reason to assume that the old models - the ones actually followed by the West, or even Japan and the Asian Tigers — should, or now, given irrevocably changed economic structures and, perhaps more importantly, fears about environmental carrying capacities, can be followed. Similarly, organizational forms that served well in the past likely will not be appropriate in the future. A return to bureaucratic public administration that served Western countries well in administering their own affairs, and often those of others, may not be the solution, but we need to identify the target objectives of public administration reforms more realistically. For developing countries, Professor Farazmand's prescription, while desirable, is anything but modest.

\section{References}

Amsden, Alice H. 1989. Asia's Next Giant: South Korea and Late Industrialization. New York: Oxford University Press.

- 1994. Why Isn't the Whole World Experimenting with the East Asian Model to Develop? Review of the East Asian Miracle. World Development 22(4): 627-33.

Chang, Ha-Joon. 2002. Kicking Away the Ladder: Development Strategy in Historical Perspective. London: Anthem Press.

Haggard, Stephan, and Robert R. Kaufman, eds. 1992. The Politics of Economic Adjustment: International Constraints, Distributive Conflicts, and the State. Princeton, NJ: Princeton University Press.

Hirschman, Albert O. 1988. The Strategy of Economic Development. Boulder, CO: Westview Press.

Hoff, Karla, and Joseph E. Stiglitz. 2001. Modern Economic Theory and Development. In Frontiers of Development Economics: The Future in Perspective, edited by Gerald M. Meier and Joseph E. Stiglitz, 389-459. New York: Oxford University Press.

Kwon, Jene. 1994. The East Asia Challenge to Neoclassical Orthodoxy. World Development 22 (4): 635-44.

Perkins, Dwight H. 1994. There Are at Least Three Models of East Asian Development. World Development 22(4): 655-61.

Rodrik, Dani. 2007. One Economics, Many Recipes: Globalization, Institutions and Economic Growth. Princeton, NJ: Princeton University Press.

Rosenstein-Rodan, Paul. 1951. Notes on the Theory of the "Big Push." In Economic Development for Latin America, edited by Howard S. Ellis and Henry C. Wallich, 57-67. New York: St. Martin's Press.

World Bank. 1993. The East Asia Miracle: Economic Growth and Public Policy. New York: Oxford University Press. 